\title{
A VÁROSI TÉRSÉGEK A KÖZIGAZGATÁSI STRUKTÚRA ÉS A „GOVERNANCE” KERESZTMETSZETÉBEN
}

\author{
(Urban Areas in the Focus of Administrational Structure and \\ Urban Governance)
}

\section{SOMLYÓDYNÉ PFEIL EDIT}

Kulcsszavak:

várospolitika közigazgatás városi kormányzás területi tervezés együttmủködés önkormányzati társulás

A városi térségek a fejlődés, a gazdasági növekedés fontos helyeiként ismét az Európai Unió és a nemzetállamok érdeklódésének homlokterébe kerülttek. A globalizáció, a jóléti állam meggyengülése, a versenyképességi kihivások a városi vonzáskörzetek, agglomerációk és városhálózatok egységes térként való kezelése érdekében a kooperációhoz új intézményesülési formákat, új szereplöket és módszereket rendelnek. A városi térségek regionális dimenzióba kerültek, közös tervezési-fejlesztési tevékenység kereteivé váltak. S tapasztalható, nem szükségszerü megoldása a problémának a mélyreható intézményi változás vagy a fennálló közigazgatási szerkezet szétfeszitése, de sikeres kormámyzás valósitható meg az urbánus terekben a ,governance” alkalmazásával és hálózati struktúrák megteremtésével is.

\section{Bevezetés}

Mind gyakrabban hangzik el a közép-kelet-európai térség új európai uniós tagállamairól, hogy nem rendelkeznek sem nemzeti várospolitikával, sem pedig az urbánus tereket integráló politikával. Holott a városi terek valójában nem konfliktust vagy akadályokat jelentenek, hanem épp ellenkezőleg, lehetőségeket és hidakat nyitnak meg a fejlődés számára. Kétségtelen azonban, hogy a városfejlỏdés dimenziói kitágultak. Egyre kevésbé a nemzeti városhierarchiában kell elhelyeznünk a városokat, mindinkább egy kitágult gazdasági térben és legalább európai kontextusban mérendó helyük és szerepük. Minthogy a városok még mindig kritikus helyei az identitásnak, a cselekvésnek és döntéshozásnak, s hasonlóképpen döntő fontosságúak a nemzeti gazdaságok számára (Parkinson 2005).

A városok, illetve a városhálózat kezelésében többféle módszer kínálkozik a közigazgatás számára a városok nagyságrendjével szoros összefüggésben. Már régóta tudjuk, hogy célszerü a városokat vonzáskörzetükkel, agglomerációjukkal, szuburbán településgyürújükkel összhangban kormányozni, hiszen a közigazgatási határokat figyelmen kívül hagyó lakossági mozgáspályák mentén aktív szolgáltatáscsere valósul meg a központi település és környéke között, mely ún. spillover hatásokat eredményez. Attól függóen, hogy a városok urbánus vagy rurális térben helyezkednek-e el, továbbá az urbanizációs ciklus mely szakaszát élik, milyen erōs 
a vonzáskörzetükhöz füzödő viszonyuk, sőt a nemzeti és nemzetközi városhálózati hierarchiában elfoglalt helyük szerint is más-más intézményesülési, illetve kooperációs formát igényelnek. A város attól város, hogy térségi szerepköröket gyakorol. Ennek tükrében a tanulmány annak a problémakörnek a boncolására vállalkozik, hogy hol tart a városi térségek intézményesítésének, kormányzásának kérdése Európában és itthon.

Kiindulópontunk, hogy az önkormányzati testületek mindenekelött igyekeznek feladataikat minél jobb minőségben ellátni, s ennek érdekében egyrészt stratégiát dolgoznak ki a központi és a szubnacionális kormányzati egységekkel való kooperáció céljából, másrészt horizontálisan más közigazgatási egységekkel is együttmüködnek, társulnak vagy szerződéses kapcsolatra lépnek egymással. Sőt, máig több európai államban létjogosultsága és jogi alapja van az önkormányzatok egyesülésének. Egyébiránt a fejlett országokban folyó kutatások az önkormányzatközi együttmúködéseket és a füziókat a területi kormányzás innovatív formájának tartják (Cepiku 2006). Némi magyarázatul szolgálhat ehhez, hogy más államok jogrendszere az önkormányzati társulások bizonyos közjogi intézményeibe beengedik a magánjogi jogalanyokat, szemben a magyar jogi felfogással (Somlyódyné Pfeil 2003).

\section{Paradigmaváltás a városi vonzáskörzeti együttmüködések nemzetközi porondján}

Azt, hogy a városfejlődési folyamat milyen mértékben bír relevanciával a közigazgatás számára, nem csupán a belsö viszonyok befolyásolják, de hatnak rá a városi térségekkel kapcsolatosan az európai közigazgatási térben zajló események is. E tekintetben nem kizárólagosan az Európai Unió kohéziós politikájára kell gondolnunk, hanem az Unió számos tagállamában a várospolitikát érintően az utóbbi évtizedben lezajlott számottevő változásokra is. A nyolcvanas évek apátiája után a városi térségek kezelése élénk szakmai viták kereszttüzébe került, $\mathrm{s}$ több régi uniós tagállamban a közjogi szabályozásnak ismételten kiemelt területévé váltak a városi vonzáskörzetek, agglomerációk. Ebben az összefüggésben egyfajta paradigmaváltás érzékelhetỏ. Amikor áttekintjük néhány országnak (Franciaország, Németország, Olaszország, Hollandia stb.) a városi vonzáskörzeti együttműködések intézményesítésére, esetleg új várospolitika megfogalmazására tett intézkedéseit, megállapíthatjuk, hogy azok összefüggésben állnak egyfelől a nemzetállamok közigazgatási szerkezetének modernizációjával és hatékonyságának javításával, másfelöl a városok gazdasági fejlődése, versenyképessége erösítésének kényszerével.

A megfigyelhető föbb tendenciák közül kiemelést érdemel, hogy

- az EU strukturális politikája egyértelmü hatással van a tagállamok várospolitikai döntéshozására. A Lisszaboni stratégia kibocsátása óta az agglomerációkban, városokban és városhálózatokban rejlő lehetőségek kiaknázása fontos kohéziós politikai céllá emelkedett. Különösképpen igaz ez a városrégiókra és városhálózatokra, 
melyek a versenyképesség és tudásgazdaság szempontjából fontos klaszterépítés eszközeivé váltak nemzeti és nemzetközi viszonylatban egyaránt.

- Hasonlóképpen kedvez a városrégiók és városhálózatok képződésének, az együttmüködések szervezeti formába öntésének a közigazgatás szférájában zajló regionalizálás és decentralizáció. Sőt, a városi vonzáskörzeti reformok az önkormányzati berendezkedés alapjait érintő közjogi változásokat is előidézhetnek, amikor például az intézményesített együttmüködés túllép a települési szint és az alsó középszint közötti szokásos feladat- és hatáskör-megosztáson és regionális léptékủ feladatokat céloz. Tehát adott esetben a regionalizáció egy válfaját is megtestesitheti. A célzott változások megjelenhetnek közvetlen demokratikus legitimációval rendelkező, integrált és kétszintủ közigazgatási struktúrák formájában, és eredményezhetik az adott városrégióban a közigazgatási szintek számának csökkenését, feladat- és hatásköri rendjének, szerkezetének egyszerüsödését.

- A tervezés, tervkészités a városkörnyékek és városrégiók vonatkozásában a hatékony irányitás és koordináció eszköze. Ezzel összefüggésben európai és nemzetállami szinten egyaránt kiemelkedő szerephez jut a tervek megvalósítása, mely rugalmas, a magángazdaságból átvett módszerek terjedését hozza magával a közigazgatásban. A területi tervezés szerepe a megváltozott peremfeltételek közepette rendkívül felértékelődött. Alkalmas eszköz ugyanis arra, hogy a városi térséget, mint összefüggő életteret kezelje, s kiegyenlítse vagy ellentételezze az egyes önkormányzatok által várostérségi szinten nyújtott szolgáltatásokat. Eredménye, hogy az egész térség fejlődésére javaslatokat dolgoz ki, melynek következtében az egyedi önkormányzati fejlesztési-beruházási tevékenységek regionális kontextusba kerülnek. Ezáltal olyan funkciómegosztás jön létre a települések között, amely saját arculatot kölcsönöz a térségnek, hogy azután alapja legyen a közös identitás felépítésének (Adam 2001).

- Az önkormányzatok közötti együttmúködések egyre gyakrabban hálózatokká szerveződve új intézményesülési formát keresnek. A közigazgatás szférája nyit a gazdasági és nonprofit szektor irányába, amelyektől pótlólagos források bevonását reméli saját céljaihoz. Végső soron ezt azzal a várakozással teszi, hogy a közszolgáltatások megszervezése és az önkormányzati gazdaságfejlesztés hatékonyabbá és eredményesebbé válik. Az önkormányzatokkal szemben egyre gyakoribb elvárás - amint az a Lisszaboni stratégiában megjelent -, hogy a gazdaságfejlesztés és a fenntartható fejlődés motorjának feladatát is betöltsék.

Érdemes azt is számba venni, hogy a gazdaságilag fejlett uniós tagállamok városhálózatának urbanizáltsága lényegesen magasabb szintü, mint a kelet-európaiaké. Következésképpen egészen más problémákkal küzdenek, mint a fáziskésésben lévő új tagállamokban. Így például ott a vidék elvárosiasodása folyik a város és vidék közötti különbségek nivellálása érdekében. E folyamat negatívuma a városi vonzáskörzetek széttöredezésében, a városok körül létrejövő átmenet nélküli ún. települési masszában csapódik le. A lakó- és iparterületek immár határok nélkül belenőnek a 
vonzáskörzetekbe. Bírálatok érték az utóbbi időben az EU által forszírozott policentrikus városfejlesztési koncepciót, mivel fennáll a veszélye annak, hogy a városok úgyszintén egymásra nőnek és felolvadnak egy differenciálatlan „településpépben". Magukat a városcentrumokat is veszély fenyegeti, hiszen tradicionális városi miliojjüket veszíthetik el (Kühn 2001).

\section{Várakozások és kételyek a ,governance” irányában}

A politika- és közigazgatás-tudományi diskurzus tárgya már hosszabb ideje a „governance" fogalma, mely nem csak a politikatudományban, de mindinkább a területi tudományban és a területfejlesztéssel összefüggésben keresi a helyét. A közösségi cselekvés új fogalma leginkább a kormányzás (government) hagyományos fogalmához képest helyezhető el. Megjelenése az állam visszavonulását fejezi ki a hagyományos hierarchikus irányitási eszközöktől, illetve a társadalmi problémák közvetlen szabályozásától és ellenörzésétől. A governance alkalmazása esetén a piactól átvett kormányzási módszerek lépnek a kötelező szabályok helyébe. A ,governance”, mint az önigazgató kormányzás fogalmát egyszer a modern közigazgatási müködéssel, a New Public Managementtel, másszor a regionális együttmüködéssel és regionális hálózatokkal azonosítják. Országonként mást-mást értenek alatta, de a legtágabb kiindulópontját jelentő idea „a szereplök változó körének horizontális kordinációja" (Frey 2005, 451).

A globalizáció táplálta gazdasági, illetve telephelyi verseny és a fenntartható fejlődés jövőképe új kihívások elé állítja a városokat és régiókat akkor, amikor fejlödési pályájukat kialakítják, $\mathrm{s}$ e vonatkozásban fontos eszközként jön számításba a regionális kormányzás („regionális governance”) és a városi kormányzás („urban governance”). A „governance” komplex kormányzási és koordinációs struktúrákat jelent, melyek formális és informális elemeket, állami és nem állami szereplőket éppúgy átfognak, mint hierarchikus, piaci és kooperatív viszonylatokat (Benz 2001, 55). Az „önkormányzás” puha módozata, amely elsősorban hálózatokra alapozódik, következésképpen létrejötte tanulási folyamatot jelent, melyben a konfliktuskezelés magas szintre kell, hogy jusson. Minthogy az együttmüködő szereplök konkurensei is egymásnak win-win megoldások keresésére irányul (Fürst 2003).

A regionális és a városi kormányzás feltünése markáns változásokat hozott a területfejlesztési politika elméletében és gyakorlatában. A „regionális governance” tételezése szerint megkülönböztethető a funkcionális és területi „governance” fogalma. Eszerint a funkcionális fogalom a regionális fejlesztés problémáira és témáira reagál, számára lényegtelenek a közigazgatási, sőt a földrajzi határok is. A területi „governance” számára viszont a lehatárolt régió adja a cselekvés keretét. Az utóbbi szereplöi leginkább kompetenciákban és intézményekben gondolkodnak, míg a funkcionális „governance” szereplöi folyamatokban és problémák menedzselésében (Fürst 2003). Mindenesetre témánk szempontjából az a lényeges, hogy mind a funkcionális problémarégió, mind pedig a területi közigazgatási régió problematikája 
egyaránt a területi fejlỏdés állami irányítása számára keresi az alkalmas léptéket és szintet. Ily módon a „governance-vita” a gazdásági és politikai struktúraváltás következtében az állami szerepfelfogás módosulását kôzvetíti, a regionalizáció fontosságát, amely a városokat és régiókat egyaránt pozícióba helyezi a tőkéért, a pénzért, az árukért és a munkáért folytatott globális versenyben (Pütz 2006). A városi és regionális kormányzás „rokonai” egymásnak, mivel számos önkormányzat egyedi döntéseinek egymással való egyeztetését foglalja magában valamely régió, agglomeráció vagy metropolisz térség kiegyensúlyozott fejlödését célozva. Mindekőzben mindkettő valamely régió léptékú tér versenyképességét, társadalmi (életminőség, kohézió) és ökológiai (környezet és erőforrásvédelem) szempontjait tartja szem elött a fenntartható fejlödés égisze alatt (Frey 2005, 561).

Az újfajta kormányzás normatív tartalmán a közvélekedés általában azt érti, hogy az a régiók és városrégiók kormányzási képességét erösíti, vagyis autonóm jogi személyek kollektív cselekvési képességét hozza létre. Ennek vonatkozásában érzékeny kérdés a kollektív cselekvés intézményesültségének foka, minthogy fö sajátossága szerint az állami, gazdasági és civil szektor együttmüködését laza horizontális struktúrában és intézmények nélküli térben valósítja meg. A városi kormányzás ritkán hoz létre új szervezeteket, általában meglévők közötti, gyakran személyfüggö kooperációként müködik egy közös, jó célra orientáltan. Ugyanakkor a szükséges konszenzus létrejötte és a kooperáció eredményének gyakorlati megvalósítása mégiscsak feltételezi az intézményesülés minimális mértékét, és vele együtt a szereplők kőzötti bizalmat, az átláthatóságot, vagyis elkerülhetetlenné teszi a kormányzásnak, legalább, mint együttmúködési folyamatnak a szabályozását. Mind többen vallják, hogy a regionális és városi kormányzás mégiscsak igényel egy szervezeti magot, mint adminisztratív struktúrát, továbbá egy rögzített vezetési funkciót, például annak érdekében, hogy a fejlesztési egység kifelé képviselhető legyen és számára a pénzügyi források elérhetőkké váljanak.

Mindenesetre a városi kormányzás nem a globalizáció elleni védelmi szövetség, hanem épp ellenkezőleg, szereplői számára lehetővé teszi a globális folyamatokban való részvételt (Priddat 2006, 255). Problémakezelö eszközről van szó, amely azokra a kérdésekre válaszol, melyek a hagyományos lokális keretek között, lokális kapacitásokkal és közigazgatási struktúrákkal már nem oldhatók meg. Pragmatikus alapja, hogy egy városrégió lakói befizetett adóikért a közintézményektől megfelelő ellenszolgáltatásokban részesüljenek, jó élet- és munkakörülményeket kapjanak. A struktúrák müködtetésében a hatékonyság és az innováció irányában tett lépéskẻnt értékelödik a célok elérésébe bevont szereplök körének kiterjesztése a magángazdaság és a civil szféra irányába. A módszer alkalmazása azonban nemcsak előnyökkel jár, de általa különféle veszélyek is fellépnek, mivel létét a politikailag legitimált intézményeken kívül találja meg. Lokális szinten ugyanis a privatizáció egy válfaját is megtestesíti, amikor a politikai térbe privát szereplök vonulnak be a fennálló struktúrák hatékonyságnövekedésének reményében, miközben ezzel párhuzamosan a demokratikus kontroll alól kivonódnak a közérdekű döntések. Ez a modern, intelligens és pragmatikus eszköz - politikai legitimáció hiányában - 
tagadhatatlanul az államnak és a demokratizmusnak a visszaszorulását eredményezheti. Ezzel szemben az EU Fehér könyve az Európai kormányzásról, épp ellenkezőleg, a „governance”-on keresztül az európai politizálás nyitottságának és átláthatóságának növekedését várja (Komission... 2001). Az iménti negatív megközelítésnek a finomítását jelenti, hogy a ,governance" közvetítette együttmüködés bizonyos esetekben elöképe egy szorosabb szervezeti forma későbbi megszületésének, amikor a laza kooperációt egy politikailag legitimált és államilag szabályozott intézményi struktúra váltja fel (Wortmann 2006).

\section{A városhálózati együttmüködés, mint ,governance-modell”}

A városhálózatok intézménye összekapcsolódik a policentrikus gondolkodásmóddal, s noha azt feltételeznénk, hogy ez új keletü megközelítés, akkor nagyot tévedünk (Faragó 2006). Az Európai Unió számára a Lipcsei Irányelvekkel (1994) értékelődött fel a fogalom, s azóta mind fontosabbá válik a tagállamok várospolitikájában.

A városhálózati együttmüködésekben a pontszerúen elhelyezkedő városok közötti kapcsolatokon van a hangsúly, ezekben az együttmüködési formákban nincs helye a város és kömyéke viszonylatnak. Városhálózatok akkor szoktak létrejönni, amikor a strukturális problémákkal küzdö, nagyvárosi agglomerációkon kívüli területek közép- és kisvárosai hálózati együttműködésre lépnek egymással, mivel egymagában egyik helyhatóság sem tudná felvenni a versenyt a nagyvárosokkal. Többnyire a telephelyekért folytatott nemzetközi versenyben való részvétel és helytállás a definiált céljuk. A városhálózatok azonban nem csak a városi önkormányzatok, a közszereplők együttmüködését jelentik, hanem „governance-típusú” partnerségi kooperációkat takarnak, amelyekben a szinergia-hatások elérése érdekében a gazdasági és civil szféra is részt vesz. A szakemberek azonban hangsúlyozzák, hogy célmeghatározó tényezöiknek mindvégig az önkormányzatoknak kell maradniuk.

A városhálózati modellek sohasem holisztikus célok szolgálatában állnak, hanem problémaorientált szervezödések, amelyek gyakorlati projektek megvalósítására jönnek létre. Noha az együttmüködések mindig önkéntesek, azokat mégis egyfajta kényszer szüli: a nagyvárosok agglomerációjukkal együtt versenyképes szereplöi tudnak lenni a területi fejlödésnek, viszont a közepes méretú és kisvárosok saját erejükböl nem tudnak megfelelni a gazdaság és a $\mathrm{K}+\mathrm{F}$ támasztotta komplex telephelyi feltételeknek. A városok nemzetközi versenyében való helytállás érdekében a városok hálózati együttmüködésre lépnek egymással, amiből komparatív elönyöket kívánnak kovácsolni. A hálózat együttes cselekvése regionális hatást céloz, regionális, illetve interregionális fellépést tesz lehetővé nemzeti vagy akár nemzetközi szintéren. Ebből következően a városhálózat létrejöttének célja a regionális kérdések irányításában-alakításában való felelősségvállalás, regionális fejlődési folyamatok generálása (Somlyódyné Pfeil 2003).

A német minta szerint a városhálózat szervezeti formájának nincs jelentősége, azt a partnerek szabadon határozzák meg. Az lehet közjogi és magánjogi forma egy- 
aránt. A regionális menedzsment eszközeinek használata azonban annál lényegesebb, mivel konkrét feladata közös projektek implantációja a gazdaságösztönzés, a marketing, a technológia-transzfer, a turizmus vagy éppen a közlekedési infrastruktúra fejlesztésének területén. Viszont nagyon fontos, hogy nem ad hoc csoportosulások ezek, hanem a városok közép- vagy hosszú távú kooperációját takarják egyfelöl közös üzleti célok megvalósítására, másfelől a településstruktúra decentralizációjának megerősítéseképpen (Melzer 1997).

Az új fejlödési irány magyarázata abban keresendő, hogy a minöségi követelmények a városok versenyében egyre fontosabb szerepet játszanak. A városok feladata olyan üzleti szolgáltatások letelepítése, differenciált közszolgáltatások, valamint minőségi élettér és környezet biztosítása, amely a magas jövedelemmel bíró kvalifikált rétegek infrastrukturális és szolgáltatási igényeit ki tudja elégíteni. A városok alkotta hálózatok az új és nehezülő kérdésekre kooperatív és egyúttal hatékony válaszokat tudnak adni. A városhálózat akkor múködöképes, ha a társuló önkormányzatok szabad akaratán alapul és a szereplők által kiérlelt és közösen kiválasztott együttmüködési súlypontok végrehajtását szolgálja. A tematizált önkormányzati együttmủködések e fajtája számára a közigazgatási határok irrelevánsak. A közös szervezetek megtestesíthetnek járások, megyék, régiók, sőt országok határait is átlépö kooperációkat, melyek azonban éppen az együttmüködés céljai miatt eröteljesen igénylik a gazdasági és nonprofit döntéshozók bevonását.

A településközi együttmúködésen alapuló városhálózatok gyakorlati modellezése Németországban az 1990-es évek közepén már elindult. A föderatív államban 1992-ben a szövetség és a tartományok közösen új területrendezési tételként határozták meg a városhálózatokat, és felvették őket az ún. Területpolitikai Orientációs Keretbe (ORA), melynek köszönhetően első ízben váltak a területrendezési és regionális politika épitőköveivé. Az absztraktnak nevezhetỏ cél operacionalizálása érdekében két évvel később az illetékes szövetségi minisztérium kutatási és támogatási irányvonalat nyitott (ExWoSt) előzetes kiválasztási eljárás során megállapított hat modell-városhálózat javára. A program azonban a listát nem tekintette lezártnak (Melzer 1997, 499-450).

Hollandiában a nagyvárosi régiók közül egyesek túlzottan nagyra nőttek, így az agglomeráció-igazgatási szervezetek mind nagyobb területet fognak át, melynek ellensúlyozására célszerüen megjelent a hálózatos gazdaság mellett a hálózatos társadalom koncepciója. Az emberek és áruk növekvő mobilitása a várospolitika ủj válaszát kényszerítette ki, melynek szemléleti bázisa, hogy a lakás, a munka és az ellátás lehetöség szerint az egyes városok alkotta hálózatokon belül funkcionális egységben valósuljon meg, s a már beépített területek használatát optimalizálják. A várospolitikai kurzusváltás jegyében a holland kormány összesen 14 városhálózatot jelölt ki, mint regionális jelentőségü háloózatokat, melyek közül hat nemzetközi jelentőséggel bír. Ily módon az ezredfordulón ebben az uniós tagországban a városrégió koncepcióját a hálózati koncepció váltotta fel. Eszerint a hálózat nem egy, hanem több centrumra épül, s nem kizárt, hogy a városi hálózat nagyobb kiterjedésü, mint egy városrégió. 
A hálózati megközelítés ellenére a holland kormány szakított „a governance without goverment" megközelítéssel és egyértelművé tette az állam érdekeltségét az új struktúrákban, vagyis a közigazgatási és kormányzati egységek különböző szinteken megvalósuló együttmüködését tartja kívánatosnak a speciális problémák megoldására (Sterkenburg-Denters-Klok 2006). Stratégiai jellegủ politikai koncepcióról van szó, amely regionális fejlődési lehetőségeket nyit meg a városi tér elött a városi kormányzás új formáját reprezentálva. A közigazgatás feladata a hálózat megszervezése, az infrastrukturális adottságok jobb kihasználása, a tömegközlekedés jobbá tétele, az önkormányzatok közötti megállapodások tető alá hozása, valamint a közös gazdaságpolitika. Mindennek a kooperációban résztvevők közötti verseny kiküszöbölésének pozitív hozadékával kell együttjárnia. A holland állam pedig a városi hálózatok funkcionális egységének megteremtéséhez programokon és projekteken keresztül pénzügyi eszközöket biztosít (Van der Burg 2001; Sterkenburg-Denters-Klok 2006).

\section{A nagyváros, mint régió}

Tekintettel arra, hogy az önkormányzatok gazdasági környezete megváltozott, s a régiók között mind nemzeti, mind nemzetközi szinten kiélezödött a verseny, az 1990-es évektől kezdődően a területi tudomány a nagyvárosokat mind erőteljesebben regionális kontextusban szemléli. A regionalizáció bizonyos intézményi feltételek közepette lehetövé tudja tenni a terület- és városfejlesztés hatékony irányitását azáltal, hogy a gazdasági, ökológiai, szociális és kulturális fejlődést egyazon városi térben kezeli. A városi térségek egybeszervezésének hagyományos szemlélete a domináns városközpont és vonzáskörzetének modellje egy hierarchikus városhálózaton belül, mely életre hívta a városrégió fogalmát. A városrégió mint intézmény elsőként talán a holland urbanizációs politikában kapott helyet 1966-ban, azóta pedig széles körben elterjedt. A városrégió fogalma a várost és térségét, mint egységes életteret fedi le, melyben kezdenek feloldódni a centrum és vonzáskörzete közötti különbségek, a funkciók és mozgáspályák már egyáltalán nem egyirányúak, hanem kiegyenlitődnek.

A szakmai érdeklődés középpontjában a nagyvárosi régiók állnak, ez azonban nem zárja ki, hogy középvárosok esetében is használható legyen a fogalom. Ugyanis a városi térségek besorolása szempontjából ma már nem csak a népességszámnak van jelentősége, hanem a központosultságnak, a gyakorolt funkcióknak, a népsürüségnek, valamint a városépitészeti struktúrának és a fejlődési dinamikának egyaránt. Néhány éve például Németországban a Német Épitésügyi és Területrendezési Szövetségi Hivatal (Bundesamt für Bauwesen und Raumordnung) 62 városrégiót határolt le, melyek legkevesebb nyolcvanezer lakosú városközpontból, magterületből és ingázási vonzáskörzetből állnak és specifikusan valamely nagyváros-környéken fekszenek (Adam 2005). 
Az 1990-es évektől kezdődően ismét reneszánszát éli a nagyvárosi igazgatás, de egy módosult intézményi szemléletben, amit a térbeli szereplők komplexitása és a közös cselekvés fejez ki a partnerség és rugalmasság elvén alapulva. Ennek a változásnak a hátterében a központi állam visszavonulása rejtőzik a közszférában zajló decentralizáció, privatizáció, dereguláció következtében (Lefêvre 1998). Holott az államnak hosszú ideje természetes magatartása, hogy saját intézményei útján közvetlenül vagy közvetve részt vesz a különféle városigazgatási és városhálózati modellek alakitásában.

A nagyvárosi terek intézményesítése fỏként Nyugat-Európában több évtizedes fejlỏdési ívet ír le, és kezdetben feltétlenül közjogi szervezeti formákban öltött testet. Számos esetben az 1960-as években alapitott egyszerủ városkörnyéki társulástól és az elővárosi közlekedés megszervezését biztosító tarifaszerződésektől az ezredfordulóig eljutottak a regionális hatású cselekvés küszöbére. Időközben a szervezetek funkcionális irányultsága is átalakult, a nagy hálózati infrastruktúrák közös és hatékony müködtetésétől eljutottak a komplex gazdasági tér igényelte közös tevékenységekig, valamint a közszolgáltatások hálózatos megszervezéséig. Ezzel azt kívánjuk érzékeltetni, hogy az intézményesülés mögött hosszú, evolutív fejlödés húzódik meg, mely számtalanszor szervezetek megszünésén, egyesülésén vagy átalakulásán keresztül vezetett el egy komplexnek tekinthető modell létrejöttéhez.

Olaszországban például az 1990-es években a városok és vonzáskörzetük együttes fejlesztését célzó, a korábbiaknál hatékonyabb tervezési módszerek bevezetésére került sor. Az olasz közigazgatásban a helyi önkormányzati reform eredményeként jöttek létre az új közigazgatási szintet megjelenítő ún. metropolisz térségek. E térségeket (Milánó, Velence, Torino, Genova, Bologna, Firenze, Róma, Nápoly, Bari, Palermo, Catania) az érintett régiók jelölték ki ott, ahol kialakult a helyi önkormányzatok szoros egymásrautaltsága a gazdasági tevékenység, a föbb közszolgáltatások nyújtása és a kulturális kapcsolatok vonatkozásában. Az új közigazgatási egységek választott testülettel rendelkeznek, melyek felelősségi körébe bizonyos közszolgáltatások megszervezésén, az útfenntartáson, a kulturális és környezeti vagyon védelmén felül a metropolisz térségre kiterjedó tervezés is beletartozik.

A megteremtett kétszintü igazgatási rendszer lényege, hogy alapszintjét az autonómiájukat megőrző települési önkormányzatok, második szintjét az agglomeráció önkormányzata adja. A térség irányítása a Metropolisz Tanács, a Metropolisz Bizottság, valamint polgármestere kezében van. A metropolisz térség tehát hatalmat gyakorol a települési szint felett, ami vitathatatlanul radikális beavatkozást jelent a helyi önkormányzatok működésébe. Gyakorolja a térségi jelentőségủ, valamint a területi koordinációt igénylő hatásköröket (kulturális és környezeti értékek védelme, helyi erőforrások védelme stb.). A változások horderejét mutatja, hogy a metropolisz térség fogadja el az ún. terïleti koordinációs tervet (piano territoriale di coordinamento). Az utóbbi tervtípus a stratégiai tervek típusába tartozik, s koordinálja a térség valamennyi helyhatóságának gazdasági, területhasználati és környezet-igénybevételi terveit. 
A települési önkormányzatokhoz képest a metropolisz térségeknek kedvező a helyzetük, saját pénzügyi bázist birtokolnak, mely adóbevételekből és a szolgáltatások díjaiból tevődik össze. Ez megfelelő mozgásteret kínál az ún. végrehajtási tervek megalkotásához és megvalósításához. Az utóbbiakhoz kapcsolódik aztán az új keletủ programszerződés intézménye, mely az állami finanszírozást biztosítja, ha a végrehajtás érdekében létrejött a területileg érintett összes helyhatóság egyetértése (European Commission 2000). A tervezési tevékenység nem csak Olaszországban alkotja a nagyvárosi együttmüködési intézmények központi kérdését, hiszen a városrégió (urban region) egységes fejlesztési tervezése egészen más minőséget testesít meg, mint a városközpont és az agglomerációban elhelyezkedő helyi önkormányzatok terveinek egyszerü összessége.

Korántsem ennyire homogén a német nagyvárosok és agglomerációjuk együttmüködésének intézményesülése. Talán a föderatív államberendezkedés is útját állta egy típusos kooperációs szervezeti forma létrejöttének, hiszen az önkormányzati rendszer szabályozása tagállami hatáskört alkot. A tizenöt német nagyváros és térsége együttmüködésének intézményesítésére négy alkalmazott szervezeti formát különböztetnek meg:

1) a községek beolvadását, fúzióját a városközpontba,

2) a városkörnyék-szövetséget,

3) a városrégiót vagy más néven regionális járást,

4) a városállamok együttmüködését a határos tartománnyal.

Témánk szempontjából az első három szervezeti megoldás érdemel figyelmet. El kell ismerni, hogy a nagyvárosok és az azokat övezö községek egyesítése a II. Világháborút követő területi reformok óta a régi tartományok bármelyikében keresztülvihetetlen, viszont az új német tagállamokban az 1990-es évek végén Lipcse és Drezda esetében a szuburbanizáció okozta népességvesztést és vásárlóerö-csökkenést a vonzáskörzet önkormányzatainak a nagyvárosokba történő beolvasztásával sikerült kiegyenlíteni. Drezda esetében azonban a kiterjesztett nagyvárosi önkormányzatot alkotó helyhatóságok azóta „Drezda régióvá” egyesültek, melynek a delegáció elve alapján épül fel a legfőbb döntéshozó szerve - a polgármesterek konferenciája. Az együttmüködés kifejezett célja a versenyképes régió megteremtése a telephelyekért folytatott versenyben, továbbá önkormányzatközi iparterületek fejlesztése.

A kooperáció máig legnépszerübb formáját a városkörnyék-szövetségek alkotják, melyek alapjait az 1911. évi Nagy-Berlin Célszövetségi törvény fektette le. Az együttműködések fókuszában általában a városi térség egészére megvalósított tervezési tevékenység, a gazdaságösztönzés, a nagyvárosi-elővárosi tömegközlekedés megszervezése és müködtetése, és nem utolsó sorban a regionális identitás kialakítása áll. A célszövetségek eredményes müködésük határát többnyire pénzügyi eszközeik elégtelenségében találják meg, ami sokszor útját állja a közös tervek maradéktalan megvalósításának.

Látszólagos ellenmondás feszül aközött, hogy önkormányzati társulási típust testesít meg a városkörnyék-szövetség, ugyanakkor az állampolgárok által közvetlenül 
választott döntéshozó szervet is birtokolhat, amint ezt a Frankfurti VároskörnyékSzövetség és a Stuttgarti Régiószövetség bizonyítja. A közvetlenül választott szövetségi gyülés a nagyvárosi térséget politikai programszintté teszi. Így a pártküzdelmek által meghatározott döntéshozás segít áthidalni az önkormányzatközi kooperációból adódó konfliktusokat és növeli a városrégióban való gondolkodás és cselekvés esélyét. A Frankfurt környéki célszövetség Frankfurt városán kívül még öt, vele határos járás és egy járási jogú város együttműködését intézményesíti másfélmillió lakossal. Területe eltér a regionális tervezési régió határaitól, aminek elsősorban nem területrendezési- és tervezési, hanem politikai célszerüségi indokai vannak (ARL 1999).

Értékelésként megállapítható, hogy a Frankfurti Városkörnyék-Szövetség tervezésmódszertanilag a legfejlettebb tervezési szövetség Németországban. Ugyanakkor éppen ezen a feladatterületen látszik, hogy az intézmény alapját jelentỏ kỏzvetlen képviselet létjogosultsága vitássá tehetö. A frankfurti szövetség müködésének egészét tekintve az agglomerációs tervezésben a leghatékonyabb és legeredményesebb, éppen ott, ahol a törvényhozónak az önkormányzati modellt fel kellett adnia. A jogilag adekvát megoldás a tagönkormányzatok kamarájának (községi kamara) bekapcsolása lett, mivel a területhasználat tervezése az önkormányzatok Alkotmányban garantált joga. Miután a szövetségi gyülésben az önkormányzatok intézményes képviselete nem biztosított, szükségessé vált egy olyan szerv létesítése, amelyben a szövetségi tag városok és községek közvetlen képviselethez jutnak. Képviseletük független nagyságrendjüktöl, ugyanis egy-egy hely és szavazat illeti meg öket a kamarában. Egyébiránt azokon a feladatterületeken, amelyeken a kapcsolódó döntések a szövetségi gyúlésben születnek, a szervezet munkáját az önkormányzatokkal fennálló gyakori konfliktusok hátráltatják. Tehát szembe kerül egymással a közvetlenül választott szerv önkormányzati jellemzöje az erős és öntudatos önkormányzatokkal, melyek települési érdekeik érvényesítésére törekszenek (Fürst-Ritter 1993).

Jelenleg a politikailag legitimált, teljes integrációt jelentö, ún. „regionális járás” megalapítása jelenti a városrégiók intézményesítésének betetözését Németországban. Elsỏ realizálása 2001-ben a Hannoveri régió megszületésével történt meg, mely egy közvetlen választással létrejövő kétszintủ önkormányzati régiót valósított meg új területi közigazgatási szint létrehozásával. A regionalizációs koncepció lényege, hogy mind a hannoveri járást, mind a korábbi agglomeráció-igazgatási szervet feloszlatták, míg Hannover városa elveszítette járási jogállását annak érdekében, hogy az ún. „regionális járás”, mint valamennyi szervezet jogutódja megszülessék (Kleine-Sellnow, L.-Sellnow, $R$. 1999). Ez a régió-modell tehát szétfeszítette a német közigazgatás hagyományos struktúráját.

A reform egészének értéke a két irányban végrehajtott decentralizációval mérhető: egyfelöl a területi államigazgatás egyes funkcióit áldozta fel a régió intézményének oltárán, másfelől a járási szint kiiktatásával az integrált települési önkormányzatokat tette (pl. építéshatósági hatáskörök, oktatás, közlekedési hivatal stb.) a felszámolt hannoveri járás után még fennmaradó feladatkörök hordozóivá. Az agglome- 
rációt alkotó települési önkormányzatok természetesen megtartották jogi önállóságukat. A régió létrehozásának lényege leginkább az igazgatási szintek számának csökkenésében és a feladatok újratelepítésében ragadható meg. A hannoveri régió kompetenciájában több közigazgatási szervtől leválasztott feladat- és hatáskört egyesít: a kormányzati kerülettől, mint államigazgatási szervtől, önmaga elödjétől, a nagyváros-szövetségtől és a hannoveri járástól egyaránt átvett feladatokat. A törvénytervezet készítői tekintettel kívántak lenni a lakosság igényeire, ezért a Hannover városát megillető feladatkörök zömét ugyan átruházták a regionális járásra, ám a polgárokhoz közeli igazgatás megkívánta hatáskörök az önkormányzatoknál helyben maradtak a reform után is (Kleine-Sellnow, L.-Sellnow, R. 1999). Végül érdemes megemlíteni, hogy a megvalósult régió-modellben felfedezhető a területi tervezési együttmüködés integráló ereje, hiszen a négy évtizedes együttműködés után célba ért régió egyúttal regionális tervezési egység, illetve annak jogosultja AlsóSzászország tartományban.

A nagyvárosi agglomerációk kezelésében a bemutatott hagyományos közjogi megoldások képviselik az egyik vonulatot, míg azokat kiegészíti a velük akár párhuzamosan is jelen lévő fontos fejlödési irányvonal, a flexibilis partnerségi modell, az ún. városi kormányzás, melynek kulcsszava a „szerződés és az eljárásmód”. Ugyanis a nagyvárosi térségekhez kapcsolódó várospolitikát mindjobban olyan szerződések fedik le, amelyek az állam és a helyi önkormányzatok, vagy pedig az önkormányzatok és nem közszereplök között jönnek létre (Jouve-Lefêvre 2002).

\section{Kis-és középvárosok, valamint környékük viszonya}

A városi vonzáskörzeti problematika megragadásának még mindig egyik pillére az önkormányzatok közötti horizontális együttmủködés. A településközi együttmúködési formák a legnehezebben a városkörnyékek viszonylatában jönnek létre, mert az önkormányzati aktorok között bizalmatlanság uralkodik, mindegyik fél attól tart, hogy a másik oldal túlzott előnyökre tesz szert. Viszont a kooperáció igénye a legerőteljesebben itt jelentkezik. Az önkormányzati társulások hagyományos intézménye a rurális térségekben alkalmas kerete a városokra, mint központokra alapozott ellátási-szolgáltatási funkciók megszervezésének, a közszolgáltatások kiegyenlített hálója költséghatékony és egységes színvonalú megszervezésének. A városkörnyéki együttműködések nem a városi kormányzás mintaadó modelljei, hanem az egyenértékủ életfeltételek garantálásának eszközei a közszolgáltatások színvonalas és koncentrált biztosítása érdekében. $\mathrm{S}$ nem mellékesen alkalmasak a használati spillover hatás kiküszöbölésére az adók és jövedelmek kiegyenlítése révén. $\mathrm{E}$ városkörnyéki kooperációk lehetnek informálisak és formalizáltak egyaránt, leggyakrabban azonban közjogi szabályozást nyernek.

Szinte lehetetlen feladatnak látszik a kis- és középvárosok körüli vonzáskörzeti együttműködések tipizálása, hiszen országonként és még országokon belül is eltérő eszköz- és intézményrendszer kapcsolódik hozzájuk. Ha mégis kísérletet teszünk az 
önkormányzati kooperációk szervezeti formáinak meghatározására, akkor a közösen ellátott feladatok karaktere szerint három fö típust lehet elkülöníteni (GawronJähnke 2000):

1) a hagyományosan szigorú közigazgatási szervezeti struktúrákban mủködő, átfogó jellegü városkörnyék-szövetségeket;

2) a konkrét közös projektek végrehajtására szervezödö önkormányzati együttmúködéseket, mely kategória speciális válfajaként nevezhetôk meg a „governance-struktúrák”, illetőleg a public-private partnerségi konstrukciók (az ủn. PPP-modell);

3) községek és városok ún. ágazati feladatok megvalósítására irányuló tematikus együttmüködéseit.

A városi vonzáskörzetek önkormányzatainak ágazati együttmüködéssel érintett különös tárgykörei lehetnek az összehangolt lakásépítés és telekgazdálkodás, a helyközi közlekedés müködtetése, valamint iparterületek, ipari parkok közös létesítése és müködtetése stb. (Mensing-Wittekind 1997). A különféle kommunális infrastruktúrák, közszolgáltatásokat biztosító intézmények (oktatási, kulturális, sport, egészségügyi stb.) közös fejlesztése és üzemeltetése, mint gyakori kooperációs területek nem jelentenek specifikumot a községi önkormányzatok társulásaihoz képest, s a szervezeti formák megválasztásában sem tapasztalható szignifikáns különbség, közjogi és magánjogi együttműködési intézmények egyaránt az önkormányzatok rendelkezésére állnak. A városkörnyéki együttmủködések akkor tesznek szert kulön státuszra, ha az állam kiemeli öket a közigazgatás általános rendszeréből és megkülönböztetett funkciókat rendel hozzájuk, a vidéki térségektôl eltérỏen intézményesíti öket. Ez természetesen mindig várospolitikai kérdés.

A magyar közigazgatás permanens reformját éli, azonban felfigyelhetünk arra, hogy az Európai Unió több régi tagállama is meghirdette a közigazgatás szervezeti struktúrája megújításának programját, mely az „Új közmenedzsment” megvalósítása eufórikus hulláma után még mindig talál bóségesen feladatokat. Valamennyi országot szinte drámai mértékben érinti a népességfogyás demográfiai folyamata, amely válaszokat csikar ki a nemzeti kormányzatokból a költségvetési források beszúkülése okán. A költséghatékonyság, a gazdaságosság kérdése a közszolgáltatás-szervezés területén az érdeklödés fókuszába emelte az önkormányzatok, illetve a feladatellátás optimális mérete problematikát. Több ország város és térsége komplex szervezeti megközelítése révén törekszik a közszolgáltatások méretgazdaságosságát elérni, $\mathrm{s}$ ennek jegyében újabban elkerülhetetlenné válik a városok térségi funkcióinak és ellátási körzeteinek felülvizsgálata, sőt a szolgáltatás-szervezési struktúrák átalakítása is.

\section{Reflexiók és következtetések a hazai helyzet vonatkozásában}

Az uniós követelményeknek a magyar jogalkotót is továbblépésre kell sarkallniuk a városi vonzáskörzetek intézményesítése tárgykörében. A jelenlegi helyzet értéke- 
léseképpen legfeljebb a szabályozási hiányosságok foglalhatók össze, természetesen nem kimerítő jelleggel. A városi vonzáskörzetekben a közös cselekvést, az együttmüködések létrejöttét több olyan tényezö nehezíti, amelyekre a magyar közigazgatási rendszer jelenleg nem tud választ adni:

- A városi térségek együttmüködésének nincs adekvát intézménye (még a Budapesti agglomerációban sem);

- A városkörnyéki, illetve kistérségi fejlesztési tervezés és az önkormányzati hatáskörbe tartozó településrendezés viszonya tisztázatlan;

- $\quad \mathrm{Az}$ önkormányzati finanszírozás rendszere nem honorálja megfelelően a városok által vonzáskörzetük javára teljesített térségi feladatokat;

- A helyi adóbevételek önkormányzatok közötti megosztásának lehetősége ugyan adott, de szabályozatlan annak mikéntje (lásd 2004. évi CVII. törvény a települési oonkormányzatok többcélú kistérségi társulásáról). Az állam a megoldást áthárítja az önkormányzatokra, a központi finanszírozási rendszernek azzal nincs kapcsolata;

- Mindeddig nem létezett olyan állami szubvenció, amely a városi térségek közös problémakezelését támogatta volna, illetve nem érzékelhető az állami felelösségvállalás szándéka.

Érdemes felfigyelni arra, hogy az Országos Területfejlesztési Koncepcióban (OTK) és az Új Magyarország Fejlesztési Tervben a területfejlesztés és az állami tervezés szintjén a városhálózat egyes elemeit érintő fontos koncepcionális irányvonalak körvonalazódnak. Megjelent ismét a gondolkodásban az öt nagyváros (Debrecen, Györ, Miskolc, Pécs, Szeged), elsősorban gazdaságfejlesztési értelmezésű pólusként, miközben a közigazgatás válaszai egyelöre elmaradtak az érintett agglomerálódó térségek és a városhálózat policentrikus együttmüködésének ösztönzésére. Vagy megemlíthető, hogy az OTK a speciális adottságú térségtípusok között felvette a prioritások közé az agglomerálódó térségek harmonizációját, azonban a megvalósítás eszközrendszere gyenge, nem érzékelhető vele ősszefüggésben az állami szerepvállalás.

Külön említést érdemel az új közigazgatási szintet nem eredményezö, de az ország egészére homogén módon bevezetett többcélú kistérségi társulási rendszer, amely eredetileg a városok középfokú vonzáskörzetének lehatárolásán alapult. A pénzügyi eszközökkel erősen ösztönzött társulás célja az alapfokú közszolgáltatások kiegyenlített hálójának létrehozása, a helyi közigazgatás müködési hatékonyságának fokozása, végsỏ soron a közszolgáltatásokhoz való hozzáférés állampolgári esélyegyenlőségének megteremtése. Nyilvánvaló azonban, hogy a kőtelező földrajzi keretként rögzített statisztikai kistérségek területe általában nagyobb, mint az optimális feladatszervezés során létrejövő, mintegy a magyar közigazgatásból hiányzó integrált alapszintet modellező mikrotérségi körzetek. Ez a körülmény tagolttá, illetve belsejükben differenciálttá teszi a kistérségeket.

A városok szerepe nem lett kijelölve a kistérségi igazgatáson belül, a kistérségnek csak székhelye van, amelyhez nem rendelődtek funkciók. Hacsak azt nem számítjuk 
ide, hogy a körzetközponti (vagyis városi) önkormányzat hivatala jegyzőjéhez többlet államigazgatási hatósági feladatok telepítését rendeli el a jogalkotó. A városok térségi szerepköreinek megerősítése hiányában a többpólusú kistérségek megosztottak, városaik között hatalmi harc zajlik. E városokkal szemben a többcélú társulás, mint közigazgatás-szervezési egység gyenge, így gyakorta nem tudja a kistérségben a széttöredezett és hiányosan megszervezett ellátási struktúrákat hatékonnyá tenni. Ezen közben az állami támogatási preferenciák a kistérségi társulást erősítik, mintegy a városok térszervezỏ funkcióját helyettesítő ,pótlék szerep” betöltésére ösztökélve öket. Az állami költségvetés ugyanis jelenleg legmagasabb támogatással akkor honorálja a közszolgáltatások kistérségi ellátását, ha azt a többcélú tảrsulás által alapított vagy fenntartott saját intézmény nyújtja. Holott ésszerüen és sok esetben elegendő lenne a városi intézmények mủködési területét kiterjeszteni a kistérség többi településére, amivel viszont kevesebb kiegészítỏ forráshoz lehet jutni.

Vajon kinek jó, hogy új (esetleg a városiakkal párhuzamos) kistérségi intézmények jönnek létre, illetve, hogy rákényszerítjük városainkat intézményeik kistérségi fenntartásba adására? Az elindult folyamat nagy veszélye a funkcióiban amúgy is gyenge városhálózat, föként a kis- és középvárosok további elbizonytalanodása, térségi szerepköreinek kiürülése. Nem beszélve arról, hogy azok a többcélú társulások, amelyek ma a városok és községek kooperációját intézményesíteni tudják, a városok nagyságrendjére és térszervező erejére tekintet nélkül, homogén módon kerültek bevezetésre. Következésképpen leginkább a rurális térségek problémáinak kezelésével adekvátak, és alkalmatlanok az agglomerálódás vagy a szuburbanizáció jegyeit mutató városi térségek intenzív együttmúködésének keretbe foglalására, versenyképes szolgáltató és gazdasági térként történő egységes kezelésére.

Tehát nem halogatható tovább egy koncepciózus és differenciált várospolitika megfogalmazása, melynek egyik feladata, hogy fejlessze és tegye kiegyensúlyozottá a városhálózatot, mint életteret, másik feladata, hogy mozgósítsa a városokban meglévő erőforrásokat a versenyképessé válásra és a gazdaság motorja szerep betöltésére.

A perspektivikus várospolitika szemléleti bázisának néhány eleme:

- A várospolitika egyszerre kell, hogy jelentse a városi vonzáskörzetek differenciált intézményesítését és a fejlesztési eszközök relatíve koncentrált elhelyezését.

- A városi vonzáskörzetek kérdése mindig jövedelem újraelosztási kérdés is egyúttal. Ezért az önkormányzatok finanszírozása során vagy magának az államnak kell határozottan figyelembe vennie ezt a területpolitikai szempontot, vagy pedig olyan szabályozási konstrukciót felkínálni az önkormányzatoknak, amely például adójellegủ bevételek kivetését, de legalább újrafelosztását is lehetôvé teszi a nagyobb városi térségekben.

- A városi térségek szükségképpen közös tervezési-fejlesztési tevékenység terei, így szükséges megalkotni a különféle vonzáskörzetekre vonatkozó tervezési kompetenciákat, és viszonyukat tisztázni kell a regionális, kistérségi és településtervezéshez. 
- Az államnak célzott támogatáspolitikán, szervezeti szabályok megalkotásán keresztül iniciálnia kell a kooperációkat, esetleg bizonyos közigazgatási határok megreformálásával is válaszolhat.

Új típusú várospolitikáról akkor beszélhetünk, ha az állam koncepcionálisan megalapozott és stratégiai szemléletủ irányító tevékenysége orientálja a városok funkcionális fejlődését. A várospolitikának mentesnek kell lennie két szélsőségtől, a direkt beavatkozásoktól és az önkormányzatokra teljes egészében áthárított kooperációs elvárástól. A kontinens fejlettebb országainak tapasztalatai arra figyelmeztetnek, hogy az állam egyfelöl közigazgatási-szervezeti modellek felkinálásával, másfelöl tervezési és támogatási eszközökkel elébe megy, de legalábbis a városhálózat hóna alá nyúl fejlödésük és együttmüködésük ösztönzése érdekében. Ugyanis kiemelten fontos egy új városhálózat-fejlesztési koncepció megalkotása, amely képes differenciáltan orientálni a különböző nagyságrendü és térségi szereppel bíró városok és vonzáskörzetük integrált fejlesztését és müködtetését.

\section{Irodalom}

Adam, B. (2001) Raumplanung heute - Merkmale und Wirkungen. - Raumforschung und Raumordnung. 4.312-318. o.

Adam, B. (2005) Mittelstädte - eine stadtregionale Positionsbestimmung. - Informationen zur Stadtentwicklung. 8. 495-523. o.

ARL (Akademie für Raumforschung und Landesplanung) (1999) Grundriss der Landes- und Regionalplanung. Verlag der ARL, Hannover.

Benz, A. (2001) Vom Stadt-Umland-Verband zu ,regional governance" in Stadtregionen. - Deutsche Zeitschrift für Kommunalwissenschaften. 2. 55-71. o.

Breux, S-Collin, J-P.-Négrier, E. (2007) Political Rescaling and Municipal Cultural Public Policies: A Comparison of France and Québec. - International Journal of Urban and Regional Research. 3. 128-145. o.

Cepiku, D. (2006) Kommunale Kooperationen und kommunale Fusionen. Ein internationaler Vergleich von Reformen territorialer Governance-Strukturen. - Kleinfeld, H.-Plamper, H.-Huber, A. (Hrsg.) Regional Governance. Band I. V\&R Unipress, Göttingen. 239-266. 0.

Dubois-Maury, J. (2001) A francia területpolitika aspektusai. - Falu város régió. Város, lakás, közlekedés - Franciaországi tapasztalatok. Különszám. 49-61. o.

Écrement, B. (2001) A kiegészítö eszközrendszer és a partnerkapcsolatok formái. - Falu Város Régió. Város, lakás, közlekedés - Franciaországi tapasztalatok. Különszám. 63-83. o.

European Commission (2000) The EU compendium of spatial planning systems and policies. [Italy]. Office for Official for Publications of the European Communities, Luxembourg. (Regional Development Studies, 28/I).

Faragó L. (2006) A városokra alapozott területpolitika koncepcionális megalapozása. - Tér és Társadalom. 2. 83-102. o.

Frey, R.L. (2005) Von der Wirtschaft lernen? Governance als Managementaufgabe. - Informationen zur Raumentwicklung. 9-10. 559-565. o.

Fürst, D. (2003) Steuerung auf regionaler Ebene versus Regional Governance. - Informationen zur Raumentwicklung. 8-9.441-450. o.

Fürst, D. von-Ritter, E.-H. (1993) Landesentwicklungsplanung und Regionalplanung (Ein verwaltungswissenschaftlicher Grundriß). Werner-Verlag, Düsseldorf.

Gawron, T.-Jăhnke, P. (2000) Kooperation in der Region - Einführung und Problemstellung. - Gawron, T.Jähnke, P. (Hrsg.) Regionale Kooperation - Notwendigkeit und Herausforderung kommunaler Politik. Graue Reihe 21. IRS Institut für Regionalentwicklung und Strukturplanung, Erkner bei Berlin. 11-34. o,

Guigou, J-L.-Peyrony, J. (2004) Den Raum Frankreichs fuir 2020 planen. Vier Szenarien und ein Modell einer ,wünschenswerten Zukunft". - Raumforschung und Raumordnung. 1-2. 1-20. o.

Heinz, W. (1997) Anzätze interkommunale Kooperation: Frankfurt und die Rhein-Main-Region. Archiv für Kommunalwissenschaften. DIFU I. Halbjahresband. 73-97. o. 
Jouve, B.- Lefèvre, Ch. (2002) (eds.) Local Power, Territory and Institutions in European Metropolitan Regions. Frank Cass, London-Portland.

Kleine, W.-Sellnow, L.- Sellnow, R. (1999) Die Regionalreform der Region Hannover aus Sicht der Bürger. Ein Experiment der Bürgerbeteiligung. - Raumforschung und Raumordnung. 5-6. 437-441 . o.

Komission der Europäischen Gemeinschaften (2001) Europäisches Regieren. Ein Weissbuch. KOM (2001) 428. Brussel.

Kühn, M. (2001) Regionalisierung der Städte. - Raumforschung und Raumordnung. 5-6. 402-411 o.

Lefèvre, Ch. (1998) Metropolitan Government and Governance in Western Countries: A Critical Review. - Internation Journal of Urban and Regional Research. 1. 9-26. o.

Melzer, M. (1997) Schlüsselfragen einer zukunftsfähigen Standortpolitik mit Städtenetzen. Informationen zur Raumentwicklung. 7. 495-508. o.

Mensing, K.-Wittekind, J. (1997) Interkommunales Flächenmanagement. - Informationen zur Raumentwicklung. 7. 481-494. o.

Parkinson, M. (2005) Local Strategies in a Global Economy: Lessons from Competitive Cities. Local Development and Governance in Central, East and South-East Europe. OECD LEED Centre for Local Development, International Conference, 6-8. June. Trento.

Priddat, B.P. (2006) Netzwerk und Fusionen als drei Modelle von Regional Governance. - Kleinfeld, H.Plamper, H.-Huber, A. (Hrsg.) Regional Governance. Band I. V\&R Unipress, Göttingen. 249-259. o.

Prigge, R. (2006) Regionale Kooperation aus der Sicht der größten deutschen Städte. - Kleinfeld, H.Plamper, H.-Huber, A. (Hrsg.) Regional Governance. Band I. V\&R Unipress, Göttingen. 133-144. o.

Pütz, M. (2006) Regional Governance in der räumlichen Planung. - Kleinfeld, H.-Plamper, H.-Huber, A. (Hrsg.) Regional Governance. Band II. V\&R Unipress, Göttingen. 39-52. 0.

Somlyódyné Pfeil E. (2003) Önkormányzati integráció és helyi közigazgatás. Dialóg-Campus, Budapest-Pécs.

Somlyódyné Pfeil E. (2005) A városok az átalakuló közigazgatási rendszerekben és a területi politikában. - Magyar Közigazgatás. 4. 193-203. o.

Sterkenburg, G.-Denters, B.-Klok, P-J. (2006) Verantwortlichkeit in der Praxis. Einige Erfahrungen aus den Niederlanden. - Kleinfeld, H.-Plamper, H.-Huber, A. (Hrsg.) Regional Governance. Band I. V\&R Unipress, Göttingen. 307-319. o.

Van der Burg, A.J. (2001) Urbanisierung im Fünften Bericht zur Raumordnung in den Niederlanden. Raumordnung und Raumforschung. 4-6.427-435. o.

Wortmann, R. (2006) Regional Governance - Legitimationsprobleme einer neuen Form des Regierens. Kleinfeld, H.-Plamper, H.-Huber, A. (Hrsg.) Regional Governance. Band I. V\&R Unipress, Göttingen. 305-315. o.

\section{URBAN AREAS IN THE FOCUS OF ADMINISTRATIONAL STRUCTURE AND URBAN GOVERNANCE}

\section{EDIT SOMLYÓDYNÉ PFEIL}

The new EU member-states in the Central and Eastern European region neither possess a national urban policy, nor a policy aiming to integrate urban areas. Based on this, this study focuses on the issue of the extent to which urban networks in general possess institutions complying with the new challenges of European urban development. In what kind of context is the cooperation of urban regions embedded in several states of the EU? Should a town or city be treated as a region? The approximation of this subject takes place primarily from the point of view of regional sciences and the administrative organisations, since it is a generally accepted theory nowadays that good governance and effective institutional structures mean an important development source for regional competitiveness. From this point of view, it is important what kind of possibilities and opportunities the Hungarian towns have, including the atmosphere created by the new administration reform, and the revitalised culture of horizontal cooperation. 